\title{
EFFECTS OF AVAILABILITY OF TEACHING AND LEARNING RESOURCES ON TEACHER PERFORMANCE IN PUBLIC SECONDARY SCHOOLS IN KITUI COUNTY, KENYA
}

\author{
Ndambo Stella Mang'uu, \\ Maithya Paul, \\ Mwaura Kimani \\ School of Education, \\ Maasai Mara University, \\ Kenya
}

\begin{abstract}
:
School climate and teacher performance are critical factors in any learning institution that seeks to have competitive edge. Teachers from Kitui County have raised concern over unfavourable school climate that affects their performance. Despite the fact that some studies on school climate have been carried out in Kenya none of them has explored exhaustively on poor teacher performance. Hence there was need to carry out this study. The purpose of this study was to determine the effects of availability of teaching and learning resources on teacher performance in public secondary schools in Kitui county. this study employed mixed methods approach and descriptive survey research design to reveal and measure the opinion of teachers and the indicators of school climate and was anchored on three motivational theories namely: McGregor theory $\mathrm{x}$ and Maslow's Hierarchy of needs and Hertzberg's two factor theory. The study targeted 400 public secondary schools and 2417 teachers from Kitui county. Purposive and random sampling was used to select 40 principals and 488 teachers. Fractional method was used to sample 40 teachers from the 400-public secondary schools.20\% of 2417 teachers were randomly selected from each sub-county. Sample size for this study was calculated using hypergeometric formulae where 76 principals and 352 teachers were selected giving a total of 428 respondents. Data was collected using Questionnaires for teachers, interview schedules for principals and document analysis. Validity of the instrument was achieved by reading other research works, books and journals. Split half reliability was used to test teacher's questionnaire and principal's checklist. Research instruments were appraised through a pilot study on 25 teachers and 5 principals from Katulani sub-county. Data was analysed qualitatively and quantitatively using Pearson correlation moment to test the questionnaire, Analysis of variance (ANOVA) and multiple regression. Descriptive statistics and inferential statics were used. Descriptive statistics aided by statistical package for social sciences (SPSS) version 21.0 was used. Quantitative data was presented
\end{abstract}

${ }^{i}$ Correspondence: email stellamanguu@gmail.com 
in percentages, t-test, frequencies and tables while qualitative data was organized into thematic categories according to the objectives of the study. The study established that there is no statistically significant relationship between teaching/leaning resources and teacher performance, $p$-value $=0.001<0.00$, the study recommended that there was need for school principal to avail enough teaching and learning resources and balance teacher's workload and work closely with the teachers to ensure there is enough provision of teaching materials as well as e-resources for use by both the teachers and the students.

Keywords: teaching and learning resources, teacher performance, school climate

\section{Introduction}

For many societies' world over, education has always been the key to a promising future. Any learning intuition needs to have a favourable working environment in order to achieve success. School climate is one of the elements that contribute widely towards teacher performance and student's achievement. Hence principals who are endowed with the role management in schools should uphold healthy working school climates in a bid to promote better performance of duties and responsibilities by teachers. Adeogun and Olisaemeka (2011) defines school climate as the total measure of school characteristics such as relationships between principals and teachers, students, parents, administrators as well as the physical facilities. However, the concern on the influence of school climate on teacher performance is a global issue that needs to be investigated. The World Bank (2017) indicated existence of a learning crisis in the low and middle - income countries where it revealed that schools put a lot of emphasis on schooling without focusing on student learning. The same sentiments were put across by the America Africa Institute (2015), which indicated that many students gaining access to education in secondary schools are not gaining basic skills.

United Nations Educational Scientific Cultural Organization (UNESCO) (2016) documented the SDGs 2016-2030 of which Goal no. 4 requires all nations to provide equitable and inclusive quality education and promote lifelong learning opportunities for all by 2030. The SDGs also require that every human being acquire twenty first century skills, knowledge, attitudes and values to deal with the challenges of the world and realize a sustainable future. This can only be achieved if schools adopted the right school climate. According to Organisation for Economic Co-operation and Development (OECD, 2012), lifelong skills development will effectively address inequality, access to quality education, acquisition of essential skills for social development, labour market integration and youth unemployment challenge.

A good school climate promotes safety; healthy relationships, engaged learning and increased quality work. Teachers and principals are entrusted with the responsibility of ensuring quality performance of the students. Despite restricted resources a principal can find ways to improve teacher performance (Weathers, 2011). School climate is an 
important aspect in a school setting that influences internal and external environments including teacher performance and the overall student's achievement. School climate refers to the quality and character of school life. It is based on patterns of students, parents and school personnel experiences of school life that reflects norms, goals, values, interpersonal relationship, teaching, learning practices and organizational structures (Thapa \& Cohen, 2013). School organizational structures include human resource, curriculum, communication, finance, discipline, record-keeping and guidance.

Most researchers agree that it is a multidimensional construct that includes physical, social and academic dimensions. The physical dimension includes appearance of the school buildings and classrooms, school size and the ratio of students to teachers in the classrooms, order, organization of classrooms in the school and availability of resources (Cohen, 2012). The social dimension includes quality of interpersonal relationships between and among students, teachers and support staff, equitable and fair treatment of students by teachers and support staff, degree of competition, social comparison between students and the degree to which students and teachers contribute to decision-making at the school. The academic dimension includes quality instructions, teacher expectation for student achievement, monitoring student progress and promptly reporting results to students and parents (Cohen \& Geier, 2010).

A study carried out in USA, on increasing staff morale in today's school with increased teacher responsibilities, high-stakes testing and decreased school funding Kristina \& Shaila (2018), recommended that schools needed to make an effort to increase staff performance since it affects the school in measurable ways including student performance on high-stakes testing and school climate. The study further noted that Principals are the primary members of the school community who have the ability to make lasting impacts to improve staff performance and added that they should support teachers, provide opportunities for teachers to build healthy relationships and provide them with autonomy. Another study carried out in Georgia State on components that contribute to adequate yearly progress in elementary schools by Angeline (2010), revealed that a teacher has the potential to impact a school ability to make adequate yearly progress and emphasized the need to increase teacher motivation in order to improve performance.

Another study on the impact of organizational climate on teacher's job performance by Selamat, Samsu and Kamalu (2013), revealed that organizational climate was a significant factor that could affect teachers' job performance. The aspect of principal's leadership behaviour was found to be critical in enhancing teachers' job performance positively or negatively. As part of a study of the impact of the AIDS epidemic on education in Botswana, Malawi and Uganda, representative groups of primary and secondary school teachers were asked if they agreed with the statement that 'teacher performance at their school was high'. From their responses it was concluded that performance in Botswana and Uganda was reasonably high whereas there appeared to be more cause for concern in Malawi, especially at primary schools where teacher performance was reported to be low (Bennell \& Swainson, 2004). 
A study by Mutia (2018), on administrative factors influencing performance of girls in Kenya Certificate of Secondary Education in mixed day secondary schools in Nzambani Sub- County, Kitui County, Kenya revealed that: teachers as role models, discipline among girls and the school environment influenced girls' performance in mixed Day secondary schools in Nzambani Sub- County. The study recommended that the school principals should avail resources both physical and materials in order to improve the girls' performance in KCSE. It further recommended that the teachers' service commission should avail more female teachers to schools who would act as role models for the girls, thus improving their academic performance. The study further recommended that the school administration should establish girls' friendly school environment so as to improve their performance. Most of the studies cited on school climate are from foreign countries and very few have been carried out in Kenya especially Kitui County on the influence of school climate and teacher performance Teachers from Kitui county have raised some concerns on the challenges facing education especially in the secondary sector. Some of the critical issues mentioned were inadequate teaching and learning resources, high teaching workloads, poor principal's leadership behaviour and lack of teamwork. This study sought to address the variable of school climate namely availability of teaching and learning resources as a key indicator of school climate in the study in order to fill the existing gap.

\section{Research objective}

To establish the effects of availability of teaching and learning resources on teacher performance in public secondary schools in Kitui County.

\subsection{Research hypothesis}

There is no statistically significant relationship between availability of teaching/learning resources and teacher performance in public secondary schools in Kitui County

\section{Literature review}

\subsection{School climate}

School climate a critical element that contributes greatly towards the success of a school. It involves both internal and external environments which interact to create different types of school climates. In creating a healthy school climate, the principal plays a very vital role due to his/her management position in the school. According to Homana, Barber and Torney - Purta (2006), school climate refers to the quality and character of school life or the overall characteristics and atmosphere in the school. It is based on patterns and the safety of the school environment, experiences and principal's leadership practices (Adeyemi, 2004). Further, Getzel (2003) observed that teachers are important members of the school and play a pivotal role in educating the students. However, where the school climate becomes unfavourable, that is, where the school and physical 
environment are not safe, the principal's leadership is autocratic; this can affect teachers' job performance and students' learning outcomes.

Several types of school climates have been discussed below. The indicators of school climate are resources, teachers' workload, team building, principals' leadership behaviour, administrative support, communication, interpersonal relationships, and organizational structures for this study. Adeogun and Olisaemeka (2011) conducted a study of 10 secondary schools in Lagos State of Nigeria to determine the relationship between school climate, student achievements as well as teacher productivity for sustainable development. Their study concluded that school climate can directly influence academic performance and teacher productivity. They also found that there was a significant relationship between school climate and performance hence the need to ensure positive school climate in order to have sustainable development. A study by Maxwell, Reynods, Lee, Subasic and Broomheat (2017) from Newcastle University in Australia, on the impact of school climate and school identification on academic achievement showed that students and members of staff have a significant impact on students' academic outcomes. The findings of the study indicated that student's perception of school climate significantly explain writing and numeracy achievement affected student's identification with the school; staff school identification did not play a significant role.

Even though a handful of researches have been done with regard to school climate (Thomson, 2005; Allen 2003; Volkwelin \& Zhou, 2005; Johnsrud, Heck \& Rosser, 2000), there's still lack of studies carried out concerning school climate and teacher performance especially in Kitui County. Halpin (1967) identified 6 types of organizational climate. He classified them as: open climate, closed climate, autonomous, controlled, paternal and familiar climate.

Open climate is characterized by low disengagement, low hindrance, high intimacy, high morale and high consideration. Consideration is treating staff members as human beings. An open climate is used to describe the openness and authenticity of interaction that exists among the principal, teachers, students and parents. Hoy and Sabo (1998) stated that an open climate reflects the principal and teacher's co-operation, supportive and receptive attitudes to each other's ideas and their commitment to work. The principal shows genuine concern for teachers; motivates and encourages staff members; gives the staff freedom to carry out their duties in the best way they know; does not allow routine duties to disrupt teachers' instructional responsibilities. They care, respect and help one another as colleagues and even at personal level (Halpin, 1963). In this type of climate every teacher feels satisfied with work and there's transparency.

The second category is the closed climate. It is characterized by high disengagement, high hindrance, low morale and low consideration. The main characteristic of this type of climate is lack of commitment and or unproductively. The principal is rigid and controlling, inconsiderate, unsupportive and unresponsive. The head teacher and teachers are displeased with everything. Consequently, most teachers are frustrated and there's lack of respect for the principal (Halpin \& Croft, 1963; Hoy \& 
Sabo, 1998). This type of environment affects teachers' performance or productivity (Raza \& Shah, 2010). The third category is the autonomous climate which is characterized by complete freedom for teachers to conduct their research. The principal model's enthusiasm and diligence. Both teachers and students are happy. There's no external threat or influence. Teachers have great desire to work, and students are highly motivated to learn. The head teacher, though hard working, is relatively aloof. Aloofness refers to psychological and physical distance of the principal from teachers. The fourth category is the controlled climate this shows lesser degree of openness than both open and autonomous climate types. The climate is marked by emphasis on achievement at the expense of satisfaction of social needs There are a few genuine, warm relations among employees, but social isolation is common. All work hard but there is hardly any time for friendly relations. The head teacher is highly domineering; aloof, but not considerate. Personal problems of staff are given little emphasis. The employer is more result oriented, and bossy. He/she delegates few responsibilities and does everything to keep the school moving. The fifth category is the paternal climate. It is characterized by low aloofness. The head teacher tries hard but is ineffective in terms of productivity. He is more of a dictator while teachers do not get on well with one another. There's closeness between the principal and the teachers and the principal's expectation from teachers is impractical. The sixth category is the familiar climate. This type of climate depicts laissez - faire atmosphere. The principal is concerned about maintaining friendly atmosphere at the expense of task accomplishment. Majority of teachers are not committed to their primary assignment. Some who are committed resent the way the principal runs the school: they do not share same views with the principal and their colleagues. Those who are not committed form a clique because they are of the same attitude, they become friends. The familiarity between the principal and the teachers is so much that the institution's work suffers. The head teacher though considerate does not emphasize productivity. He acts differently from the objectives of the school while co-operation among staff is poor (Machiel, 2017). Hence the above discussed climate influences teachers' productivity since their morale is also affected.

Further, Darling-Hammond (2013), corroborated that for students to realize high achievement, teachers must possess deep content knowledge and higher order teaching skills, professional learning and realizing improvement of academic achievement in schools. Another study, by Hampden-Thomson and Galino (2017), revealed that the two factors with strongest evidence that contribute to teaching effectiveness and increases performance in students and teachers pedagogical content knowledge and quality instruction, including effective classroom management, classroom climate, professional behaviours and teacher beliefs.

\subsection{Teacher performance}

The quality of a nation's educational sector considerably depends on teachers as well as the collective interactions of the internal and external forces that intervene in the fulfilment of the purpose for setting up schools. The effectiveness and stability of the 
schools is mostly based on their school climate and the satisfaction of teachers (Wentzel \& Watkins, 2002). Performance is a function of how factors such as student characteristics, teacher's characteristics and teaching/learning resources interact in a school environment. If the interaction is healthy, the performance is always good and if not, the performance deteriorates (Akram, 2014). Another research done by Pajares (2002), observed that school resources and facilities could be a major contribution to performance in secondary schools. Sawchuck (2015) indicated that the practice of evaluating teacher performance started in 1990's in most developed countries and quickly spread to developing economies.

Stronge and Tucker (2005) conducted a study in Dallas, U.S.A with the aim of linking teacher evaluation to student learning. The study findings revealed that if high performing students were attached for some time with low role performing teachers, the performance of the students declined drastically. In this case, low performing teachers were those who experienced high rates of absenteeism, classroom misconduct and lateness in reporting to duty. Another study by Baregeya (2009), in Entebbe Municipality with an aim of establishing the influence of head teacher's general and institutional supervisory practices on teacher's work performance, revealed that most head teachers were unaware of their job descriptions and those of the teachers they led. Teachers are entrusted with duties of performing different tasks in order to influence students' achievement. Effective performance and development in schools support the ongoing development of teachers and principals to ensure that students experience high quality teaching and learning in every classroom. The indicators of teacher performance include KCSE performance, feedback, class attendance and student discipline. Demotivated teachers exhibit behaviour such as absenteeism from school, poor time management, high levels of stress, transfer from one school to another and drug abuse among others (Sharon, Raza \& Edward, 2019; Thapa \& Cohen, 2013).

Teacher quality is widely perceived as an essential determinant of academic performance, yet there is little agreement on how a teacher influences the school climate. Hanushek (2011) examines the economic value of teacher quality which is assumed to be a function of the depreciation rate of student learning, the total variation of teacher quality. The indicators of teacher performance to be considered include: level of education, experience, compensation and certification. Neal (2011) offers a useful way of thinking about how teachers respond to performance. A teacher allocates his time between different tasks and spends time coaching students and setting continuous assessment tests. The amount and quality of education a teacher receives is a logical place to start for determining the teacher quality. Teacher development does not significantly affect student's outcomes. Education and experience account for most of the variation in a teacher's salary within education and experience largely determines teachers' salaries in the United States. It is also important to provide adequate opportunities for in - service training for teachers. Inadequate in- service training opportunities deny teachers a chance to enhance their skills beyond those acquired during their pre - service basic training 
(Republic of Kenya, 2013). Instruments to reward and motivate teachers are limited as there are limited opportunities for career growth (UNESCO, 2002).

\subsection{Availability of teaching and learning resources on teacher performance}

Instruction resources play a vital role in explaining the wide variation in academic performance among students in different types of secondary schools (Kuria \& Nyabisi, 2017), noted that effective teaching depends on the availability of resources like text books and audio-visual teaching aids. Laptops and textbooks are important in the teaching learning process that can influence teachers' performance either positively or negatively. Teachers working conditions affect their ability to provide quality education. The availability of text books and other learning materials, heavy work load of teaching influences teacher performance (Akram, 2014). Before a learning resource is used in class, it must be prepared adequately and evaluated. This puts the teacher into task. Physical facilities are also important resources that support curriculum implementation (Osarenren \& Osaghae, 2012). Rochelle, Shechtman, Tatar, Hegedus, Hopkins and Empson (2010) argued that lack of most of these resources may affect teacher performance since it hampers goal achievement.

The availability of teaching/learning resources not only makes teaching and learning easier and enjoyable, but also motivates the teacher. This may not be the case in sub - Saharan Africa as (UNESCO, 2002), observed that most sub - Saharan countries faced chronic shortages in both physical and human resources. According to Hoop, rather than distributing the limited resources available for secondary education uniformly across schools, many governments allocate a relatively large share of available resources to a select number of secondary schools where the largest share is usually allocated to schools in the country's cities, neglecting the rural areas in most cases (UNESCO, 2004). Also, Bennell (2002), carried out a study on teacher motivation and incentives in subSaharan Africa and Asia and recommended that more research needed to be done in this area for human resource development. In another study, done by Kurdziolek (2011), on classroom resources and impact on learning in Virginia, revealed that resources themselves are not self-enacting, that is, they do not make change inevitable and that differences in their effects depend on differences in their use (Maxwell, 2017). Classroom instruction can be described by the relationships and interactions between teachers, students, materials, and their environment which form part of the school climate. Another study carried out from four districts in Uganda by (Madina, Wokadala \& Bategeka, 2010), showed that supplying more teaching resources in the current Uganda context should not be the number one priority intervention if the quality of education in public primary school is to be improved.

Paradoxically, supply of teaching resources is found to have adverse effects on quality education. This suggests that supply of teaching resources in these schools seem to be done at the expense of effective teaching. The study recommended on urgent need by the ministry in charge of education to focus more on teacher supervision and to compel teachers to attend to their duties and apply learner centred methods of teaching. 
This calls for increased budget for school inspection and teacher supervision. Therefore, according to this study teaching/ learning is affected by teaching methods employed and not majorly by resources. Otieno (2017) noted that the failure or success of national education system depends on quality and quantity of teaching and learning materials. Reference materials are important for teachers and students to refer to when teaching and learning is to take place. The teaching learning resources could include textbooks, set books, teachers' guides, reference books, models, field trips, charts, calculators, computer and internet. These resources help that learner to work independently as well as the teacher can help students get reference materials that they can refer to when studying. The documents ensure there is proper preparation and planning of the implementation of curriculum hence improved teacher's performance as well as students' achievement (Ngure, 2012).

Adejumobi, Faislat, Ojikutu and Rasheed (2013) did a research in Lagos state, Nigeria, on school climate and teacher job performance and found out that teacher job performance was affected by availability of facilities, class size, leadership style, motivational strategies and teacher morale. Lack of motivation among teachers is believed to have affected the performance of students in Kenya for quite some time (Kimundo, 2012). According to Jackson (1997), lack of motivation among teachers has been manifested in teachers unwillingness to participate in school activities, poor class attendance, unexpected absence, late coming, lack of additional training, uncreative and non-stimulating teaching strategies, lack of interest in meetings, unhelpful attitudes when assistance is needed, occurrence of hold-up because deadlines are not kept, resistance to contributing more than what is required of them and development of arguments among colleagues.

A study carried out by Herzbeg, Mausner and Snyderman (1959) shows the importance of hygiene factors. The study reported that, preschool teachers whose 'hygiene' needs are satisfied, became warm, sensitive and nurturing. The teachers in these studies showed great responsiveness, gave encouragement to children and used less negative disciplinary techniques. As a result, children developed positive emotional adjustments and their cognitive, language and social skills were enhanced. Additionally, the children displayed fewer behavioural problems and became socially competent. These positive child outcomes clearly demonstrate the need to motivate teachers by providing the necessary teaching/learning resources.

Lack of motivation is perceived to be determined by different factors such as immediate social and physical work environment and rewards by teachers. Saleem ( 2014), has pointed out the key determinants of teacher motivation which includes, large class size, double shifting, rural location, high educational attainment and active parental involvement. These determinants are what Veronica and Gabriel (2020) called microsystems.

Therefore, it is paramount to create conditions that will motivate secondary school teachers to initiate positive interactions with children and a physical environment that is conducive both to teachers' work and student's development. According to Ndanu 
(2018), in order to create these conditions, parents in Kenya need to participate in addressing what Herzberg, Herzberg Mausner, Synderman and Snyderman (1959), termed 'hygiene' factors or 'job context' needs. These include physical working conditions, salary, benefits, job security, and interpersonal relations.

E-learning is more potentially powerful teaching and learning tool that can attribute to positive and high productivity in developed economics over the past decade (UNESCO, 2010). It plays a role in addressing access and equity issues among students hence a life change tool in improvement of performance of such students as well as schools. Ghavifekr and Rosdy (2015), in their study on teaching and learning with technology effectiveness of ICT integration in schools, found out that the teachers are well equipped and prepared with ICT tools and facilities in the major success of teaching and learning. This implies that e-learning plays a major role in teachers' performance in schools. Rachel, Gladys Naftal and Wesonga (2015) carried out a study on effects of availability of teaching and learning resources on the implementation of inclusive Education in pre-school centers in Nyamira North sub-County, Nyamira County in Kenya which revealed that there were inadequate teaching and learning resources at Nyamira North Sub County. About 78 percent of the respondents revealed that inadequate teaching and learning resources affected the implementation of inclusive education. The study recommended that adequate teaching and learning resources should be provided to ensure effective implementation of inclusive education and more funds to be allocated for procuring teaching learning materials for special needs Education (SNE) learners. This study sought to identify how availability of teachinglearning resources affects teacher's performance.

Maeda, Musa, Tomada \& Mohammed (2017) showed that the teacher is the most important factor of the teaching - learning process. If what the teacher requires is not sufficient, or it is inadequate, to them, then it becomes a problem for them to perform their duties as required. Omondi (2010) carried out a study on teaching/learning resources and academic performance in mathematics in secondary schools in Bondo district, Kenya and concluded that the physical aspect of school climate, especially classrooms, laboratories and textbooks against the number of students could be used to predict academic performance in mathematics which affects teacher performance either positively or negatively. The study recommended review of curriculum, in-servicing of trained teachers, recruiting more competent teachers, motivation of learners, improved government support to education, good teaching methods, improved students - book ratio and better remuneration of teachers as factors that the government and all stakeholders should pay more attention to in order to improve performance in mathematics. If resources are adequately availed academic performance will increase thus increasing teacher performance. 


\section{Research Methodology}

This study employed mixed methods approach and descriptive survey research design. The study targeted 400 public secondary schools and 2417 teachers from Kitui County. Purposive and random sampling was used to select 40 principals and 488 teachers. Fractional method was used to sample 40 teachers from the 400 -public secondary schools. $20 \%$ of 2417 teachers were randomly selected from each sub-county. Sample size for this study was calculated using hypergeometric formulae where 76 principals and 352 teachers were selected giving a total of 428 respondents. Data was collected using Questionnaires for teachers, interview schedules for principals and document analysis. Validity of the instrument was achieved by reading other research works, books and journals. Split half reliability was used to test teacher's questionnaire and principal's checklist. Research instruments were appraised through a pilot study on 25 teachers and 5 principals from Katulani sub-county. Data was analysed qualitatively and quantitatively using Pearson correlation moment to test the questionnaire, Analysis of variance (ANOVA) and multiple regression. Descriptive statistics and inferential statics were used. Descriptive statistics aided by statistical package for social sciences (SPSS) version 21.0 was used. Quantitative data was presented in percentages, t-test, frequencies and tables while qualitative data was organized into thematic categories according to the objectives of the study.

\section{Results and Discussion}

\subsection{Influence of availability of teaching /learning resources on teacher performance}

Resources are used directly and indirectly to support, facilitate, influence or encouraging knowledge transmission or acquisition, competence and skills. Sarah and Simon (2017), found that availability of resources had a positive impact on teacher's job performance. This study sought to establish the relationship between availability of teaching/learning resources and teacher's performance by seeking the opinion of the teachers. The results are as shown in Table 1.

Table 1: Availability of teaching/learning resources on teacher's performance

\begin{tabular}{|l|c|c|c|c|c|c|}
\hline & BASE & $\begin{array}{c}\text { Strongly } \\
\text { Agree }\end{array}$ & Agree & Neutral & Disagree & $\begin{array}{c}\text { Strongly } \\
\text { Disagree }\end{array}$ \\
\hline \multirow{2}{*}{ 1. Textbooks are adequate } & 342 & 171 & 83 & 07 & 81 & 0 \\
\cline { 2 - 7 } & $100 \%$ & $50 \%$ & $24.26 \%$ & $2.04 \%$ & $23.68 \%$ & $0 \%$ \\
\hline \multirow{2}{*}{$\begin{array}{l}\text { 2. Availability of reference } \\
\text { materials }\end{array}$} & 342 & 25 & 151 & 05 & 150 & 11 \\
\hline \multirow{2}{*}{$\begin{array}{l}\text { 3. School has functional } \\
\text { projectors }\end{array}$} & $100 \%$ & $7.30 \%$ & $44.15 \%$ & $1.46 \%$ & $43.85 \%$ & $3.21 \%$ \\
\hline \multirow{2}{*}{$\begin{array}{l}\text { 4. E-resources are available } \\
\text { in school }\end{array}$} & $100 \%$ & $5.55 \%$ & $52.33 \%$ & 2.04 & $21.63 \%$ & $18.42 \%$ \\
\hline \multirow{2}{*}{$\begin{array}{l}\text { 5. E-resources are available } \\
\text { to teachers }\end{array}$} & $100 \%$ & $19.00 \%$ & $40.05 \%$ & $3.50 \%$ & $22.22 \%$ & $15.20 \%$ \\
\cline { 2 - 7 } & 342 & 11 & 161 & 11 & 96 & 63 \\
\hline
\end{tabular}




\begin{tabular}{|l|c|c|c|c|c|c|}
\hline \hline \multirow{2}{*}{$\begin{array}{l}\text { 6. Teachers use demonstrations } \\
\text { during subject delivery }\end{array}$} & 342 & 114 & 198 & 16 & 14 & 0 \\
\cline { 2 - 7 } & $100 \%$ & $33.33 \%$ & $57.89 \%$ & $4.67 \%$ & $4.09 \%$ & $0 \%$ \\
\hline $\begin{array}{l}\text { 7. Teachers use child centred } \\
\text { methods while teaching }\end{array}$ & 342 & 67 & 223 & 17 & 34 & 1 \\
\cline { 2 - 8 } & $100 \%$ & $19.59 \%$ & $65.20 \%$ & $4.97 \%$ & $9.94 \%$ & $0.29 \%$ \\
\hline
\end{tabular}

\subsection{Textbooks are adequate}

A majority of the respondents totaling 50\% strongly agree and $24.26 \%$ agree that there were adequate textbooks while $23.68 \%$ disagreed. Slightly over $2.04 \%$ were neutral. This implies that when textbooks were available then the students can learn ahead of the teachers. A majority of the principals $(80.0 \%)$ indicated that there was availability of textbooks in their respective schools while the other 20 percent noted that there are subjects that lacked enough textbooks. These results are further shown in Figure 1.

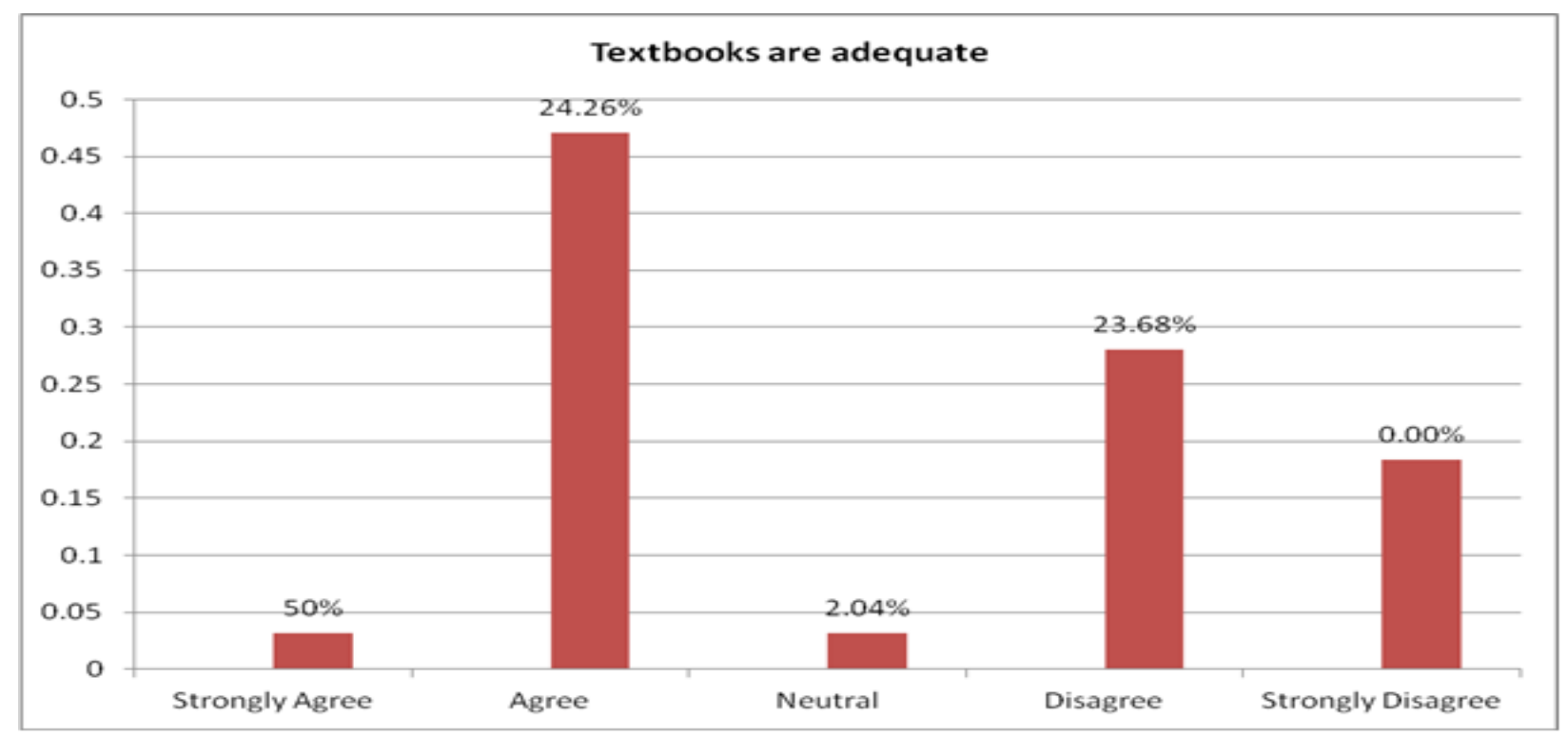

Figure 1: Textbooks were adequate

The results imply that the principals and teachers were in agreement that their schools had adequate textbooks. According to Sara and Simon (2017), the failure or success of a nation's education system depends on the quality and quantity of teaching and learning resources. This is in support of Hertzberg's two factor theory, (1959), which postulated that at the work place are the hygiene factors (dissatisfiers) which included salary, organization policy and administration, supervision, interpersonal relations and working conditions. The presence of these factors leads to high performance while their absence leads to the opposite.

\subsection{Availability of reference materials}

Further, $7.30 \%$ strongly agree and $44.15 \%$ agree of the teachers that material of reference where available. However, $1.46 \%$ was neutral about the availability of adequate reference materials in their schools. A good number of the teachers $43.85 \%$ and $3.21 \%$ disagreed 
and strongly disagreed respectively that there were adequate reference materials in their schools. This is further illustrated in Figure 2.

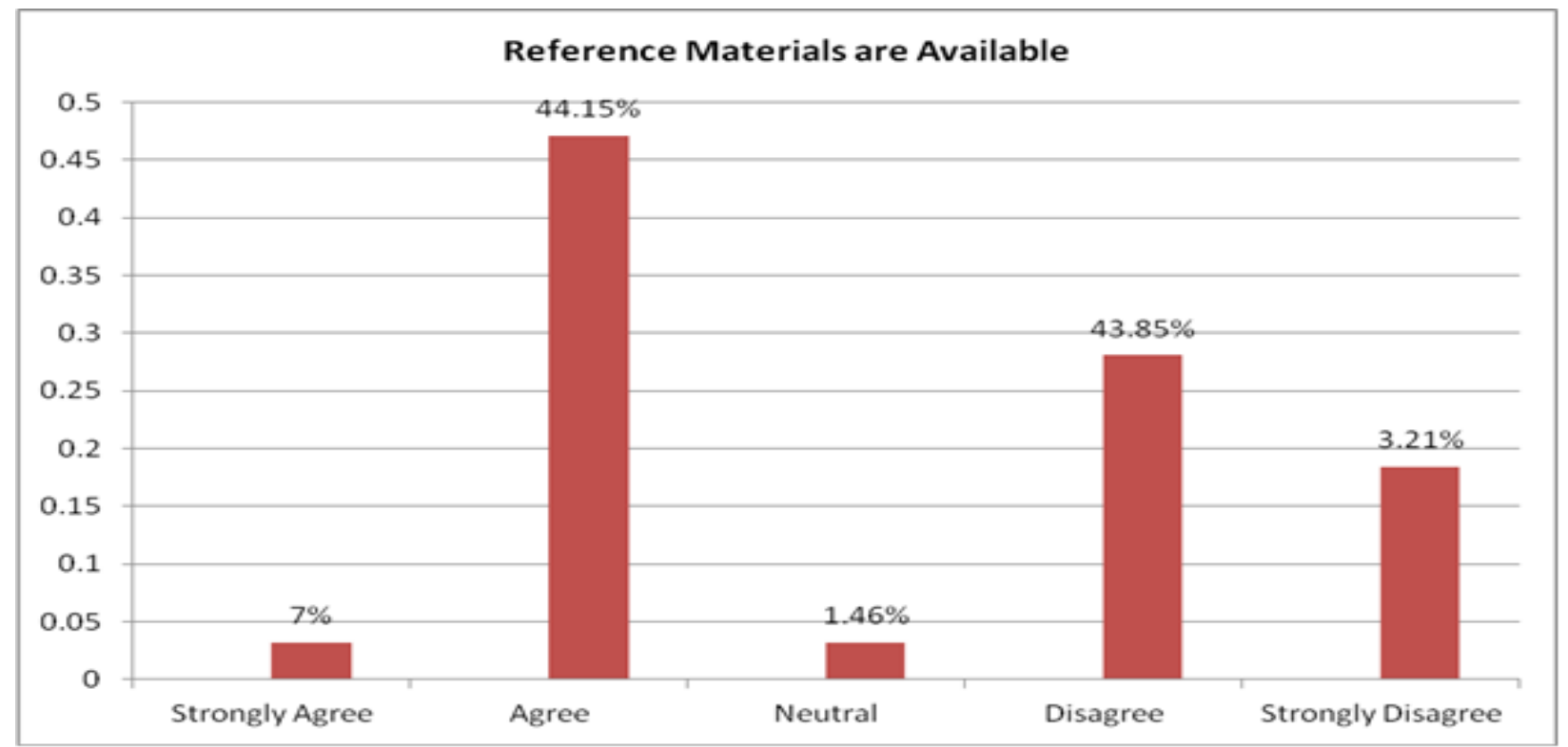

Figure 2: Reference materials were available

The study findings show that reference materials such as text books were available for lesson preparation and sometimes the schools lack other reference materials that could be used by the students to research more on certain topics as requested by the teachers. This implies that both teachers and students are able to make reference on the available reference materials especially online. The results agree with those of Osarenren, Osaghae and Irabour (2012), who asserted that availability of reference materials strengthens learning and teaching hence improvement of the teacher and students' performance.

\subsection{There are e-resources in the school}

Availability of e-resources in the school the study sought to establish whether secondary schools had e-resources available for enhancement of teaching and learning. Of the respondents, 59.05\% were in agreement that e-resources were available for teaching and learning purposes while $37.42 \%$ refuted the presence of e-resources in their schools. Only $3.50 \%$ remained neutral. The results are clearly illustrated in Figure 3. 


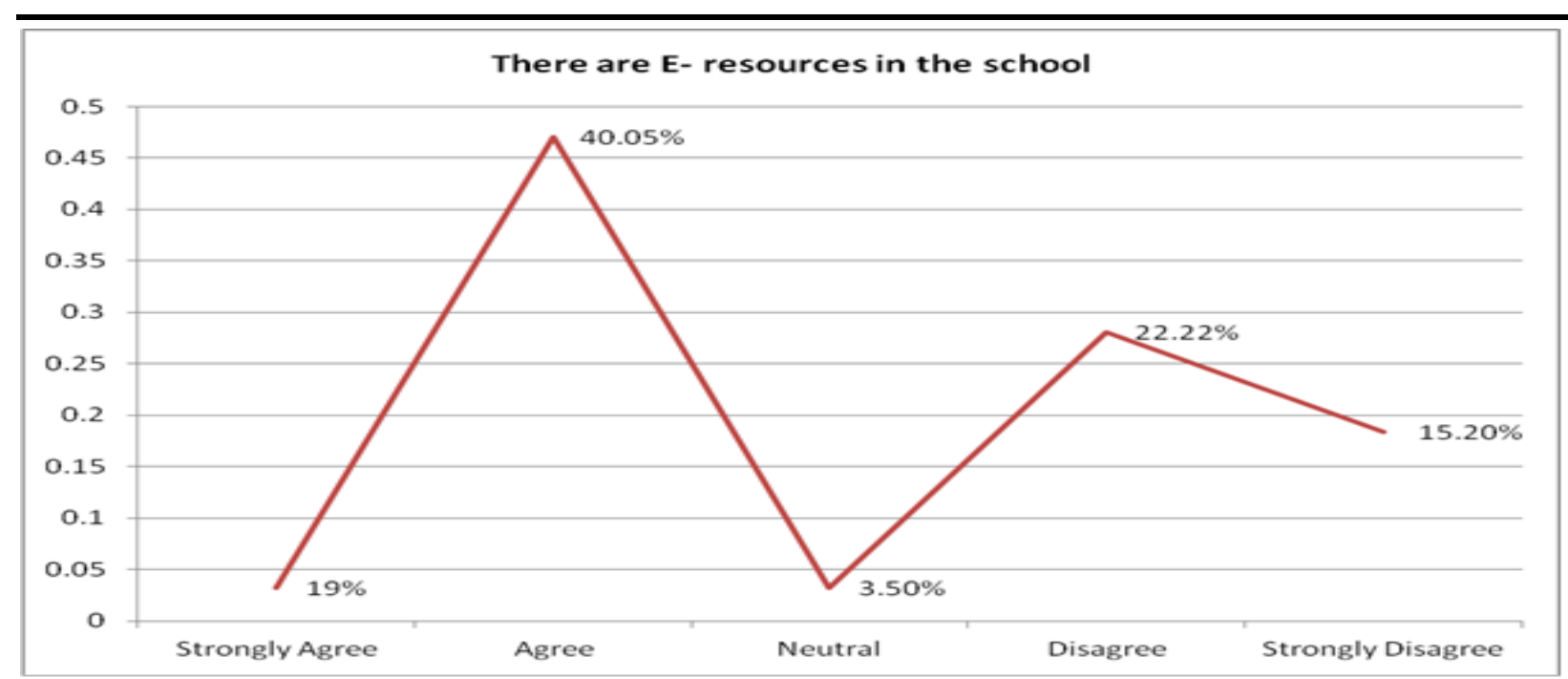

Figure 3: There were e-resources in the school

This implies that most of the schools had e-resources as indicated by majority of the teachers. However, the principals indicated that e-resources were inadequate in their schools as 24 of them (42\%) responded that e-resources were available while 33 (58\%) negated. However, the discrepancy in the responses could be an indication that the principals' target of equipping the schools adequately with e-teaching/learning resources had not been met, while the teachers felt that they were well taken care of in terms of eresources.

\subsection{E- resources were available to teachers}

The study sought to find out whether e-resources were available to teachers. The results of the study show that 161 respondents (47.07\%) agreed while $11(3.21 \%)$ strongly agreed that e-resources were available to teachers for use during teaching and learning. However, 159 respondents, representing $46.49 \%$ of the study population either disagreed or strongly disagreed to the availability of e-resources to teachers. Only 11 respondents $(3.21 \%)$ remained neutral. However, these findings are contrary to the response by the principals whose majority (49), representing $86 \%$ of the principals indicated that there were no e-resources, while only $8(14 \%)$ confirmed that their schools availed e-resources to teachers. 


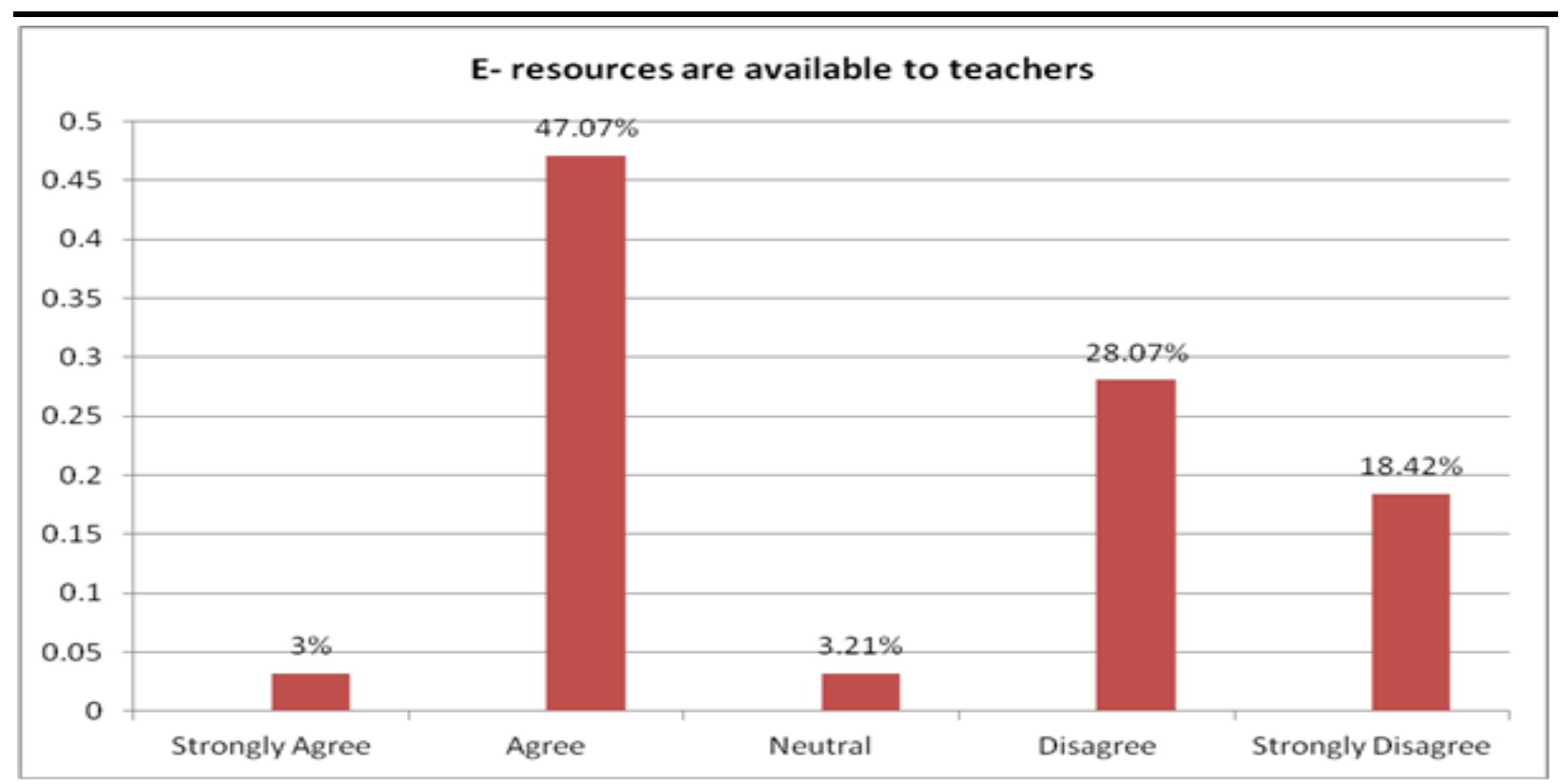

Figure 4: E-resources were available to teachers

Ghavifekr and Rosdy (2015), concurs with these findings since they found that elearning helped the teachers to be well equipped in the subjects resulting in improved teacher performance. E-resources have an impact on the day-to-day teaching and learning process. When a teacher incorporates e-resources in teaching and learning the students are able to get new insights to what they are learning. The principal's noted that e-learning was an important part of learning, but a majority of the schools had not accomplished this although the government had provided schools with few computers in the computer lab which students could share. This implies that e-resources had helped the teachers to improve their way of delivering the lesson in class.

\subsection{School has functional projectors}

Projectors are an important component of e-resources. This study sought to establish whether the schools had functional projectors. Study results show that 179 of the respondents (52.33\%) and 19 respondents (5.55\%) agreed and strongly agreed respectively that functional projectors were available in the schools they served. However, many of the respondents (137) respondents representing $40.05 \%$ indicated that there were no functional projectors in their schools, while seven respondents, representing $2.04 \%$ remained neutral. On the other hand, thirty-three of the principals $(57.89 \%)$ noted that they lacked functional projectors in their respective school. Only twenty-four $(42.10 \%)$ indicated that their schools had functional projectors. The results are further illustrated in Figure 5. 


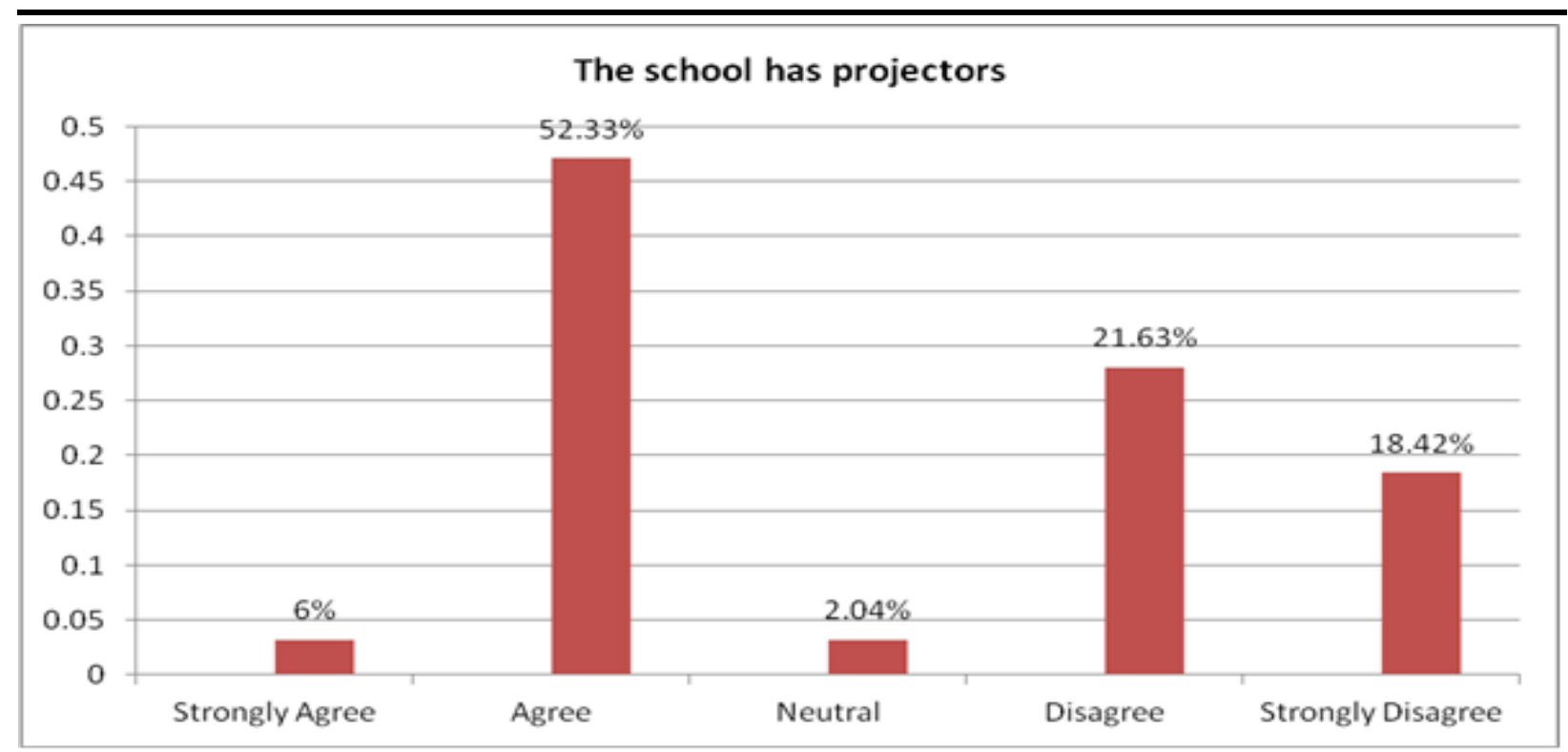

Figure 5: School has functional projectors

The study observed that when functional projects are in school, they give teachers an opportunity to offer more learning opportunities to the students through e-learning. This enhances their performance.

\subsection{Teachers use learner centred methods while teaching}

The study sought to establish whether teachers used learner centred approaches while teaching. The results show that majority of respondents (223), which translates to $65.20 \%$ agree while 67 respondents (19.59\%) strongly agree that they used child centred approach while teaching. Only seventeen (17) of the respondents $(4.97 \%)$ were not sure and remained neutral about the use of child centred approach while teaching. Thirty-five respondents $(10.23 \%)$ either disagreed or strongly disagreed to the use of child centred approach. The results are illustrated further in Figure 6.

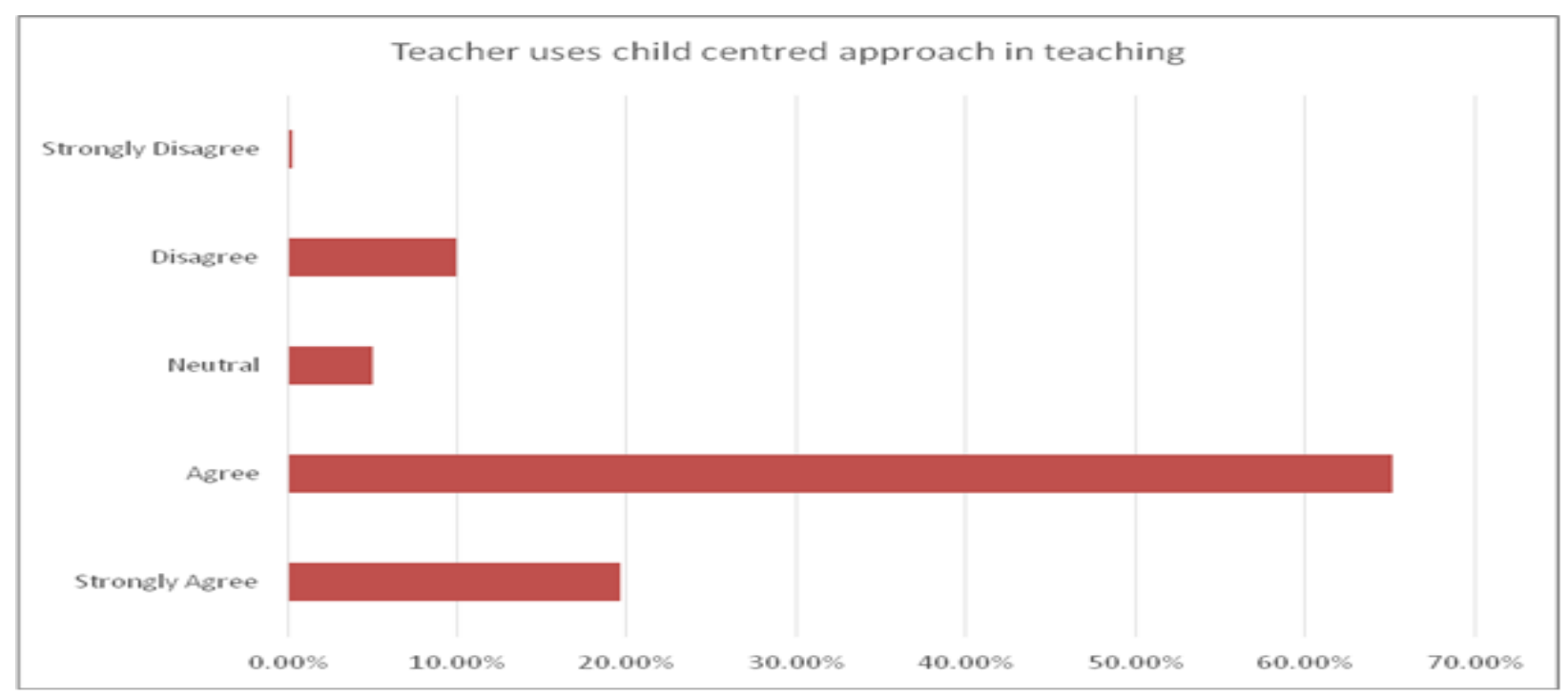

Figure 6: The teacher uses child centred approach in teaching 
The study findings imply that a majority of the teachers were using child centred approaches in teaching and learning. This is thought to be one way of improving teacher's performance. A teacher who is able to incorporate child centred learning method has big impact on students' performance. The results agree with Nelly (2016), who reported that there were benefits of teachers utilising child-centred approaches for it improved the quality of teaching and learning. The study observed that the child centred methods of teaching and learning had been advocated for, in many instances.

\subsection{Teachers use demonstration method in teaching}

The study sought to find out whether teachers used demonstration method while teaching for it was thought to influence teacher performance. The results of the study show that 114 respondents (33.33\%) and 198 (57.89\%) strongly agreed and agreed respectively that they were using demonstration method while teaching. At the same time, only 14 respondents representing $4.09 \%$ of the respondents disagreed. However, 16 respondents $(4.67 \%)$ remained neutral on whether they used demonstration method while teaching. The results are further illustrated in Figure 7.

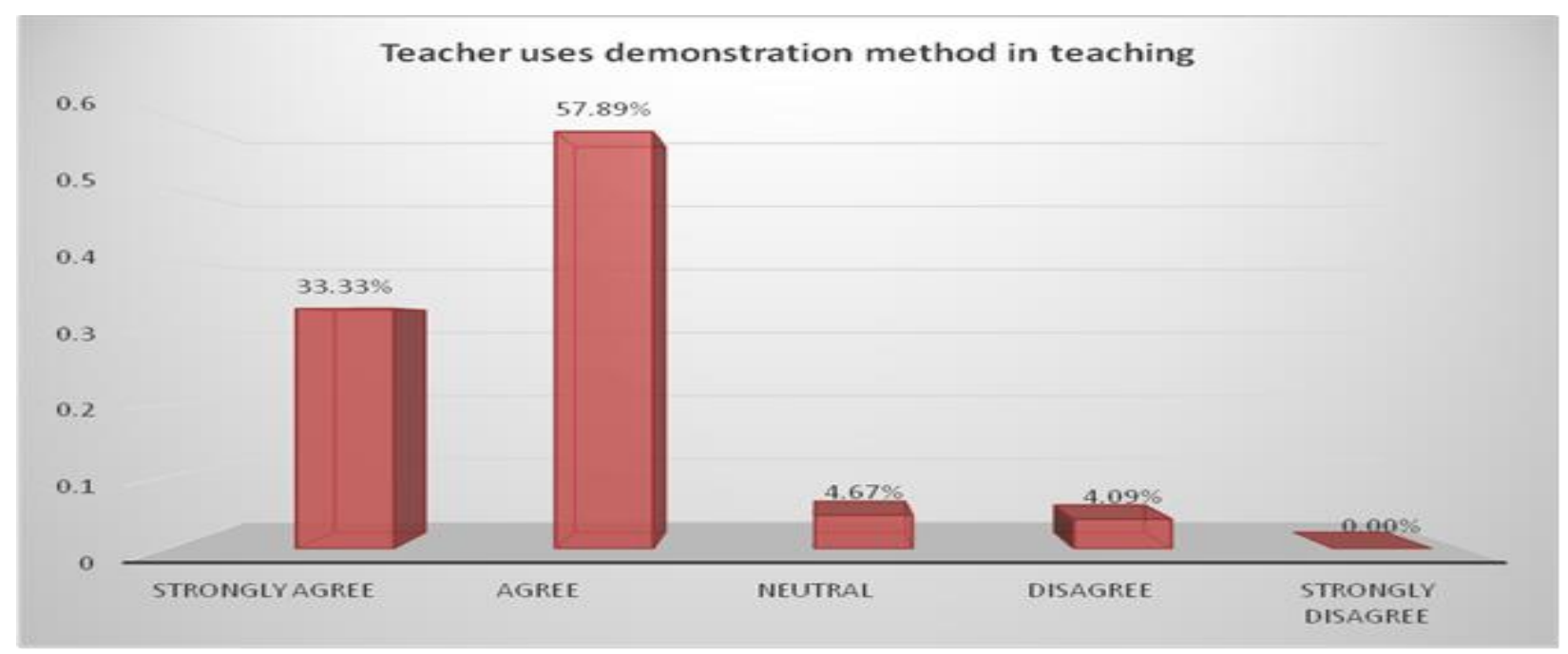

Figure 7: The teacher uses demonstration in teaching

The findings of the study indicate that a majority of the respondents were using demonstration methods while teaching. Demonstration method is just one method of content delivery that shows a teacher's passion for work, which is derived from a good school climate. This is in agreement with Herzberg's two factor theory (1959), which states that maintenance and motivational factors such as salary and working conditions contribute a lot to a worker's performance. The salary and working conditions influence the school environment as they affect the way workers perform their duties, which influence teacher performance. Hoidn (2016) opined that low morale can gradually destroy teachers' commitment and adversely affect productivity or the service delivery and alienate those they are supposed to serve (students). 
The regression model was used to establish the influence of availability of teaching and learning resources had on teacher performance. The indicator variables for teacher's performance were level of satisfaction of teachers and good students' performance. The indicators of availability of teaching and learning resources were; availability of textbooks, reference materials, functional projectors, e-resources, teacher's use demonstration in class and teachers use of child centred methods while teaching. The general multiple linear regression model formula was used:

$Y=\beta_{0}+\beta_{1} \chi_{1}+\beta_{2} \chi_{2}+\beta_{3} \chi_{3}+\ldots \ldots+\beta_{k} \chi_{k}+\varepsilon$

Where:

$\mathrm{Y}$ is the dependent variable

$\chi_{1}, \chi_{2}, . ., \chi_{\mathrm{k}}$ are the independent variables

$\mathrm{E}(\mathrm{y})=\beta_{0}+\beta_{1} \chi_{1}+\beta_{2} \chi_{2}+\ldots . \beta_{\mathrm{k}} \chi_{\mathrm{k}}$ is the deterministic portion of the model

$\beta_{1}$ the constant coefficients determine the contribution of the independent variable $\chi_{1}$ $\varepsilon_{1}$ is the random error with mean 0 and variance of 1 (Everitt \& Skrondal, 2010).

The summary output when all independent variables are included in the multiple regression equation leads to the Analysis of Variance (ANOVA). The F-test associated with the ANOVA table is used to indicate the relationship of the independent (availability of teaching and learning resources) and dependent variables. (Teacher performance). These results were attributed to quantitative data which was collected for statistical analysis using questionnaires.

Table 2: Model Summary

\begin{tabular}{|c|c|c|c|c|}
\hline Model & R & R Square & Adjusted R Square & Std. Error of the Estimate \\
\hline 1 & $.644^{\mathrm{a}}$ & .414 & .402 & .370 \\
\hline
\end{tabular}

a. Predictors: (Constant), Teacher use child centred methods while teaching, eresource have improved by work, e-resource are available, Availability of textbooks, Availability of reference materials, school has functional projectors, Teacher use demonstrations during subject delivery

b. Dependent Variable: As a teacher supplies of enough teaching and learning resources is good on teachers' performance.

Table 3: ANOVA $^{\text {a }}$

\begin{tabular}{|l|l|c|c|c|c|c|}
\hline \multicolumn{2}{|l|}{ Model } & Sum of Squares & df & Mean Square & F & Sig. \\
\hline \multirow{2}{*}{1} & Regression & 32.384 & 7 & 4.626 & \multirow{2}{*}{33.733} & \multirow{2}{*}{$.001^{\mathrm{b}}$} \\
\cline { 2 - 6 } & Residual & 45.806 & 334 & .137 & & \\
\cline { 2 - 7 } & Total & $\mathbf{7 8 . 1 9 0}$ & $\mathbf{3 4 1}$ & & & \\
\hline
\end{tabular}

a. Dependent Variable: as a teacher supplies of enough teaching and learning resources is good on performance 
b. Predictors: (Constant), Teacher use child centred methods while teaching, eresource have improved by work, e-resource are available, Availability of textbooks, Availability of reference materials, school has functional projectors, Teacher use demonstrations during subject delivery ANOVA was used to check the impact of teaching and learning resources by comparing the means of different samples

Table 4: Coefficients ${ }^{a}$

\begin{tabular}{|l|c|c|c|c|c|}
\hline \multirow{2}{*}{ Model } & \multicolumn{2}{|c|}{$\begin{array}{c}\text { Unstandardized } \\
\text { Coefficients }\end{array}$} & $\begin{array}{c}\text { Standardized } \\
\text { Coefficients }\end{array}$ & \multirow{2}{*}{ T } & \multirow{2}{*}{ Sig. } \\
\cline { 2 - 5 } & $\mathbf{B}$ & Std. Error & Beta & & \\
\hline (Constant) & 1.414 & .229 & & 6.169 & .000 \\
\hline Availability of textbooks & .135 & .020 & .340 & 6.889 & .000 \\
\hline Availability of reference materials & -.121 & .036 & -.292 & -3.332 & .001 \\
\hline school has functional projectors & -.128 & .039 & -.284 & -3.315 & .001 \\
\hline e-resource are available & .040 & .029 & .111 & 1.367 & .173 \\
\hline e-resource have improved by work & -.126 & .015 & -.370 & -8.378 & .000 \\
\hline $\begin{array}{l}\text { Teacher use demonstrations during } \\
\text { subject delivery }\end{array}$ & -.041 & .036 & -.111 & -1.154 & .249 \\
\hline $\begin{array}{l}\text { Teacher use child centred methods } \\
\text { while teaching }\end{array}$ & .017 & .048 & .024 & .349 & .727 \\
\hline
\end{tabular}

a. Dependent Variable: principals availed to teacher teaching and learning resources for good performance coefficients were used to represent the ratio of standard deviation to the mean which is a useful statistic for comparing different teaching methods. From the Model table, overall, the seven predictor variables considered for the multiple regression analysis explains 41.4 of the effect of teacher's performance. From the ANOVA table the p-value $0.01<0.05$ level of significance this means therefore there is statistically significant relationship between availability of teaching and learning resources and teachers' performance.

The Coefficient table gives the $t$-value and corresponding $\mathrm{p}$-values. The tests show there is a significance relationship between availability of teaching/learning resources and teacher performance $p$-value $=0.01<0.05$ of textbooks at $p$-value $=0.01<0.05$, availability of reference materials $\mathrm{p}$-value $0.001<0.05$, school has functional projector $\mathrm{p}$ value $=0.01<0.05$ and e-resources have improved work by teachers. This means the explanatory variables of e-resources are useful; teachers' use demonstrations during subject delivery and teachers' use of child centred methods while teaching is not useful in their model. That means in other words that availability of textbooks, reference materials, functional project and e-resources have improved work by teachers contributed significantly to teachers' performance. In this study teacher performance was measured by student achievement and discipline content delivery, feedback and lesson preparation. The study established that resource influence $(r=0.347)$ is not significant at $5 \%$ significance level. The tests show there is statistically significant no relationship 
between availability of teaching/learning resources and teacher performance $\mathrm{p}$ value $=0.001<0.005$

\section{Conclusion}

The study concluded that on the influence of availability of teaching/ learning resources such as teacher use of child centred methods while teaching, teachers used demonstration during subject delivery and teacher use of functional project had an effect on teacher's performance. The results from the ANOVA table shows there is no statistically significant relationship between availability of teaching/learning resources on teachers' performance.

\section{Recommendations}

There is need for the school principal to ensure that teaching and learning resources are availed for success on teacher's performance. The school principal therefore should work closely with the teachers to ensure there is enough provision of teaching materials as well as e-resources for use by both the teachers and the students. The policy makers should also ensure that when planning for teaching/ learning materials they are available both in soft copy and hardcopies that can be used by the teachers in teaching and learning to take place and to impact on their performance.

\section{Conflict of Interest Statement}

The authors declare no conflicts of interests.

\section{About the Authors}

Ndambo Stella Mang'uu is a PhD candidate in Educational Administration at Maasai Mara University, Kenya.

Dr. Maithya Paul is a Lecturer of Curriculum Instruction and Educational Management in the School of Education Maasai Mara University, Kenya.

Dr. Mwaura Kimani is a Lecturer in Psychology at the School of Education Maasai Mara University, Kenya. He has vast experience in qualitative and quantitative research in educational statistics, measurement and evaluation. He has long university teaching experience and student supervision.

\section{References}

\section{a. Journal articles}

Getzel, J. W. (2003). Social behaviour and the administrative process. Journal of Review $65(2), 315-373$ 
Ghavifekr, S. \& Rosdy, W. A. W. (2015). Teaching and learning with technology: Effectiveness of ICT integration in schools. International Journal of Research in Education and Science (IJRES), 1(2), 175-191.

Rochelle, J., Shechtman, N., Tatar, D., Hegedus, S., Hopkins, B., Empson, S., et al. (2010). Integration of Technology, Curriculum, and Professional Development for Advancing Middle School Mathematics: Three Large-Scale Studies. AERJ, (Online First vs. June 2, 2010).

Wentzel, K. and Watkins, D., (2002). Peer relationships and collaborative learning environment of teaching as contexts for academic enablers. School psychology Review, 31(3), 366 - 367.

\section{b. Theses}

Adeyemi, J. K. (2004). Resource situation and internal efficiency of Technical Colleges in Nigeria. PhD Thesis. University of Ibadan.

Adejumobi, F., T., Ojikutu, \& Rasheed, K. (2013). School climate and Teacher Job performance in Lagos state Nigeria. Discourse Journal of Educational Research Vol.1 June 2013,pp 26-36

Adeogun, A. A. \& Olisamaeka, B. U. (2011). Influence of school climate on students Achievement and Teachers Productivity for sustainable Development online submission US-China Educ Rev.v8 n4 552-557

Akram, M. J. (2014). Factors affecting the performance of teachers at higher secondary level. Punjab. MED Thesis, Pir Mehr Ali Shah Arid Agriculture University.

Angeline, E. M. (2010). School climate components that contribute to Adequate yearly Progress in Elementary school, A Dissertation submitted to the graduate faculty of Georgia University, Statesboro, Georgia.

Baregeya, J. (2009). Influence of Head teacher's general and Instructional supervisory Practice on teacher's work performance in Secondary Schools in Entebbe Municipality, Wakiso District, Uganda. Entebbe: Nkumba University.

Bennell, P. \& Swainson (2004). Teacher motivation and incentives in Sub-saharan Africa \& Asia, knowledge \& skills for development, Brighton

Dae, J. H., Hye, K. Y. \& Hyeonjin, K. (2010). E-Learning in the RE public of Korea, UNESCO Institute for information Technologies in Education ISBN 978-5 90517501-5 Russian

Darling Hammond L. (2013). Getting teacher evaluation right .New York, NY Teachers college press

Hampden-Thomson G. \& Galindo C. (2017). Family relationships school satisfaction and the Academic achievement of young people,Educ,Rev,69 248-265 doi.10.1080/00131911-2016.1207613

Herzberg, F., Mausner, B. \& Synderman B. (1959). The motivation to work 2nd edition. New York; John Wiley.

Hoidn, S. (2016). Student-centered learning Environment in Higher Education classroom. Palgrave Macmillan 
Hoy, W. K. \& Sabo, D. J. (1998). Quality middle school Open and Healthy, Thousand Oaks, C.A; Corwin Press.

Hoy, W. K. \& Hannum J. W. (1997). Middle school climate an Empirical assessment of Organisational Health and student achievement Educ. Admonistra. Q 33 290-311 DOI:10.1177/0013161X97033003003

Kurdziolek, M. A. (2011). Classroom resources and impact on learning; Dissertation submitted to the faculty of the Virginia Polytechnic Institute and State University in Partial fulfilment of the requirements for the degree of Doctor of Philosophy in Computer Science Blacksburg, Virginia.

Kristina, H. \& Shaila, M. (2018). Restorative Practices and the integration of social emotional learning as a path to positive school climates, Journal of Research in innovative Teaching \& Learning 11(1).110-123 DOI:10 1108/jrit-08-2017-0015

Machiel, B. (2017). Stimulating teachers team performance through team oriented HR practices: the role of effective team commitment and information doi.org/10:1080/095.192:2017.132626

Madina, M. G., Wokadala, J. \& Bategeka, L. (2010). Does teaching methods and availability of teaching resources influence pupils' performance, evidence from four Districts in Uganda. Economic Policy Research Center

Maeda, L. K., Musa, U., Tomada, D. \& Mohammed, A. M. (2017). Teaching performance and Job satisfaction Among Teachers at Region xii SSRN Electronic Journal DOI;102139/ssm.3169846 Mindanao State University, Mindanao

Metin, M. (2013). Teachers' difficulties in preparation and implementation of performance Task Journal of Educational Sciences: Theory and practices 13(3) Educational Consultancy and Research centre www.edam.com.tr/estp DOI:10.12738/ESP 2013.2.1452

Ndanu, M. C. (2017). Administrative factors influencing performance of girls in Kenya certificate of secondary Education in Nzamani sub-county Kitui County, Kenya.

Nelly, C. A. (2016). Effects of child centred methods On Teaching and Learning of Science Activities in Pre-schools in Kenya, School of Education, University of Eldoret, Kenya.

Ngure, S. M. (2012). Impact of resource utilization in education as perceived by teachers in secondary schools in Mathioya Sub County, Muranga County, Kenya. Unpublished Thesis Kenyatta University

Nunnally, J. C. \& Bernstain, I. H. (2007). Pychometrics Theory ( ${ }^{\text {rd }}$ Edition) New York: MC Graw-Hill

Sarah, S. \& Simon, H. (2017). Students Views on the cost of Access to textbooks: An Investigation at university of Otago. New Zealand, Philippa Kaeney Otago polytechnic New Zealand

Omondi, O. (2010). Teaching/Learning Resources and Academic Performance in Mathematics in Secondary Schools in Bondo District of Kenya. Kampala International University Kampala, Uganda 
Osarenren, R. I., Osaghae, \& Irabor, Q. O. (2012). Availability and Adequacy of Human and Material resources for the teaching and learning of skill-based courses in Nigeria Public Universities Department of Educational and management, Faculty of Education Alli University, P.M.B 14Ekpoma, Edo state, Nigeria.

Otieno, K. O. (2017). Teaching/learning resources and Academic performance in Mathematics in secondary schools in Bondo District of Kenya, Kampala International university Kampala, Uganda.

\section{c. Books}

Cohen, \& Geier, V. K. (2010) School climate research summary. Retrieved from http://www.schoolclimate.org/climate/school/climatebriefs.php

Cohen, J. (2012): school climate and culture improvement: A prosocial strategy that recognizes educates and supports the whole child and the whole school community. In P.M Brown, M. W Corrigan \& Higgins' Alessandro (Eds). The Handbook of prosocial Education (pp.227-270). Blue Ridge summit, P.A: Rawman and Littlefield publishing group.

Everitt, B. S. \& Skrondol, A. (2010).The Cambridge Dictionary of Statistics, Cambridge University

Halpin, A. W. \& Croft. D. B. (1963). The organisational climate of schools, Chicago, Midwest Administration Centers University of Chicago

Homana, G., Barber, C. \& Torney - Purta, J. (2006). School citizenship education climate assessment. New York: National Center for learning and citizenship Press.

Neal, D. (2011). The design of performance pays in education in E.A Hanushek, S. Machin \& L. Woessman (EDS), Handbook of economics of Education Vol. A. Amsterdam

OECD (2012). Equity and Quality in Education: Supporting Disadvantaged Students and Schools. OECD Publishing. (Online). Available at; http://www.oecd.org/edu/school/0293148.pdf. Retrieved; 19.03.2020.

Pajares F. (2002). The development of education self efficacy; development of achievement of motivation (pp.15-32), San Diego. Academic Press: CA.

Republic of Kenya (2013). The Basic Education Act 2013, No.14 of 2013. Nairobi : Government Printers

Saleem, R. B. (2014). What might be causing lack of motivation of Employees at the workplace, Istanbul Technical University

Selamat, N., Samsu, N. Z. \& Kamalu, N. S. (2013). The impact of organizational climate on Teacher's job performance faculty of education, university Technology, Mara, Shah alam, Malaysia

Stronge, J. and Tucker, P. (2005). Linking Teacher Evaluation and Student Learning. ASCD Learning. Retrieved on 19/3/2020 from http://www.edweek.org/ew/section/multimedia/teacher-performanceevaluation-issue-overview.html

Thapa, A. \& Cohen, J. (2013). A Review of school climate Research, National school climate, Shawn Guffey, Ann Higgins, D'Alless and Fordham University 
UNESCO (2016). Teachers in the Asia pacific: career progression and professional development, Bangkok office, Asia and Pacific Regional Bureau for Education

UNESCO (2004). Education for All: The quality imperative, Paris

Veronica, G. \& Gabriel, O. (2020). Determinants of parental involvement in primary schools: Evidence from Chile, Educational Review 72(20137-156 DOI :1080/00131911 2018.1487386

Weathers, M. (2011). Teacher community in urban elementary schools: the role of leadership and bureaucratic accountability. Education policy analysis Analysis, 19(3), 1-39. Retrieved from http://www.hwilsonweb.com. 
Ndambo Stella Mang'uu, Maithya Paul, Mwaura Kimani

EFFECTS OF AVAILABILITY OF TEACHING AND LEARNING RESOURCES

ON TEACHER PERFORMANCE IN PUBLIC SECONDARY SCHOOLS IN KITUI COUNTY, KENYA

Creative Commons licensing terms

Author(s) will retain the copyright of their published articles agreeing that a Creative Commons Attribution 4.0 International License (CC BY 4.0) terms will be applied to their work. Under the terms of this license, no permission is required from the author(s) or publisher for members of the community to copy, distribute, transmit or adapt the article content, providing a proper, prominent and unambiguous attribution to the authors in a manner that makes clear that the materials are being reused under permission of a Creative Commons License. Views, opinions and conclusions expressed in this research article are views, opinions and conclusions of the author(s). Open Access Publishing Group and European Journal of Education Studies shall not be responsible or answerable for any loss, damage or liability caused in relation to/arising out of conflicts of interest, copyright violations and inappropriate or inaccurate use of any kind content related or integrated into the research work. All the published works are meeting the Open Access Publishing requirements and can be freely accessed, shared, modified, distributed and used in educational, commercial and non-commercial purposes under a Creative Commons Attribution 4.0 International License (CC BY 4.0). 